\title{
Two Shell Gorgets from Southwest Arkansas
}

\section{Mary Beth D. Trubitt}

Arkansas Archeological Survey, HSU Research Station

Follow this and additional works at: https://scholarworks.sfasu.edu/ita

Part of the American Material Culture Commons, Archaeological Anthropology Commons, Environmental Studies Commons, Other American Studies Commons, Other Arts and Humanities Commons, Other History of Art, Architecture, and Archaeology Commons, and the United States History Commons

Tell us how this article helped you.

This Article is brought to you for free and open access by the Center for Regional Heritage Research at SFA ScholarWorks. It has been accepted for inclusion in Index of Texas Archaeology: Open Access Gray Literature from the Lone Star State by an authorized editor of SFA ScholarWorks. For more information, please contact cdsscholarworks@sfasu.edu. 


\section{Two Shell Gorgets from Southwest Arkansas}

Creative Commons License

(c) (i) (8)

This work is licensed under a Creative Commons Attribution-NonCommercial 4.0 International License 


\title{
Two SHELl GorgetS From SOUTHWEST ARKANSAS
}

\author{
Mary Beth Trubitt
}

Recently, there has been great interest in marine shell gorgets from the Mississippian period Southeast, not only in identifying styles or types and their geographic distributions (e.g., Brain and Phillips 1996; Hally 2007; Muller 1997), but in refining the chronology of engraved shell gorgets and other artwork (e.g., Brown 2007; Sullivan 2007). There have also been new studies looking at iconography of the engraved shell art, such as Reilly's (2007) work on the petaloid motif on Spiro shell cups as a locative that indicates a celestial location for depicted objects, individuals, or events, and Lankford's (2007) examination of Cox Mound and Hixon style gorgets as cosmological models portrayed on shell in plan and profile.

These discussions are seated on basic groundwork that identifies specific shell artifacts, the sites they came from, context and associations, and dating. In a recent article, Smith and Beahm (2009) corrected the find location (from near Rogana, Tennessee to near Rowena, Kentucky) for a shell long-nosed god mask in National Museum of the American Indian collections. They show that there is the potential for this kind of basic groundwork even with old collections.

In this article I describe and illustrate two previously unpublished marine shell gorgets from the Arkadelphia area in southwest Arkansas. Both were recovered from sites in the Middle Ouachita River region with Caddo associations. Both are curated in Arkansas Archeological Survey collections at the Henderson State University Research Station in Arkadelphia. Unfortunately neither was professionally excavated so we are lacking the important context information for these artifacts. Finds reported by amateurs or collectors need to be used with caution. Nevertheless, we can add these to the compendium of marine shell gorgets as a contribution to the database on Southeastern art and iconography.

There have been many different kinds of marine shell ornaments - ear ornaments, beads of several types, pendants, gorgets, and cups - found at Caddo sites in southwest Arkansas. Examples include engraved ear ornaments recovered from Hardman (3CL418, Clark County, Early 1993) and shell ear ornaments with copper bosses from Haley Place (3MI1, Miller County, Moore 1912), shell cups from Standridge (3MN53, Montgomery County, Early 1988), Bowman (3LR46, Little River County, Hoffman 1970; Phillips and Brown 1978), and Foster Place (3LA27, Lafayette County, Moore 1912), small plain shell pendants from Goodlett/ Ozan Site 11 (Hempstead County, Harrington 1920) and engraved zoomorphic pendants from Cedar Grove (3LA97, Lafayette County, Trubowitz 1984). This does not give a complete inventory, but suggests some of the variety of marine shell artifacts found in this area of the ancient Caddo world.

Gorgets made from marine shell are relatively rare from southwest Arkansas sites. The overview by Brain and Phillips (1996) describes 28 gorgets from Arkansas, most from counties in the northeastern part of the state; only 3 are from counties in southwest Arkansas ( 1 from Clark County and 2 from Lafayette County). The gorgets described below can be added to this list. 
The first is a plain gorget from Bayou Sel (3CL27, AAS accession number 74-248), a multi-component salt production site on the Ouachita River (Figure 1). Philip Phillips tested there during his 1939 Ouachita River Valley Survey, and Frank Schambach did brief test excavations in 1966 and 1969 (Early 1993). Based on Schambach's preliminary analysis of ceramics from the 1966-69 tests, Bayou Sel had use by Caddo Indians during what is now termed the East, Mid-Ouachita, and Social Hill phases (ca. A.D. 1100-1650; Early 2002a, b, c); available radiocarbon dates place site occupation between the late 1200s and early 1600s cal A.D. Bayou Sel was placed on the National Register of Historic Places in 1974.

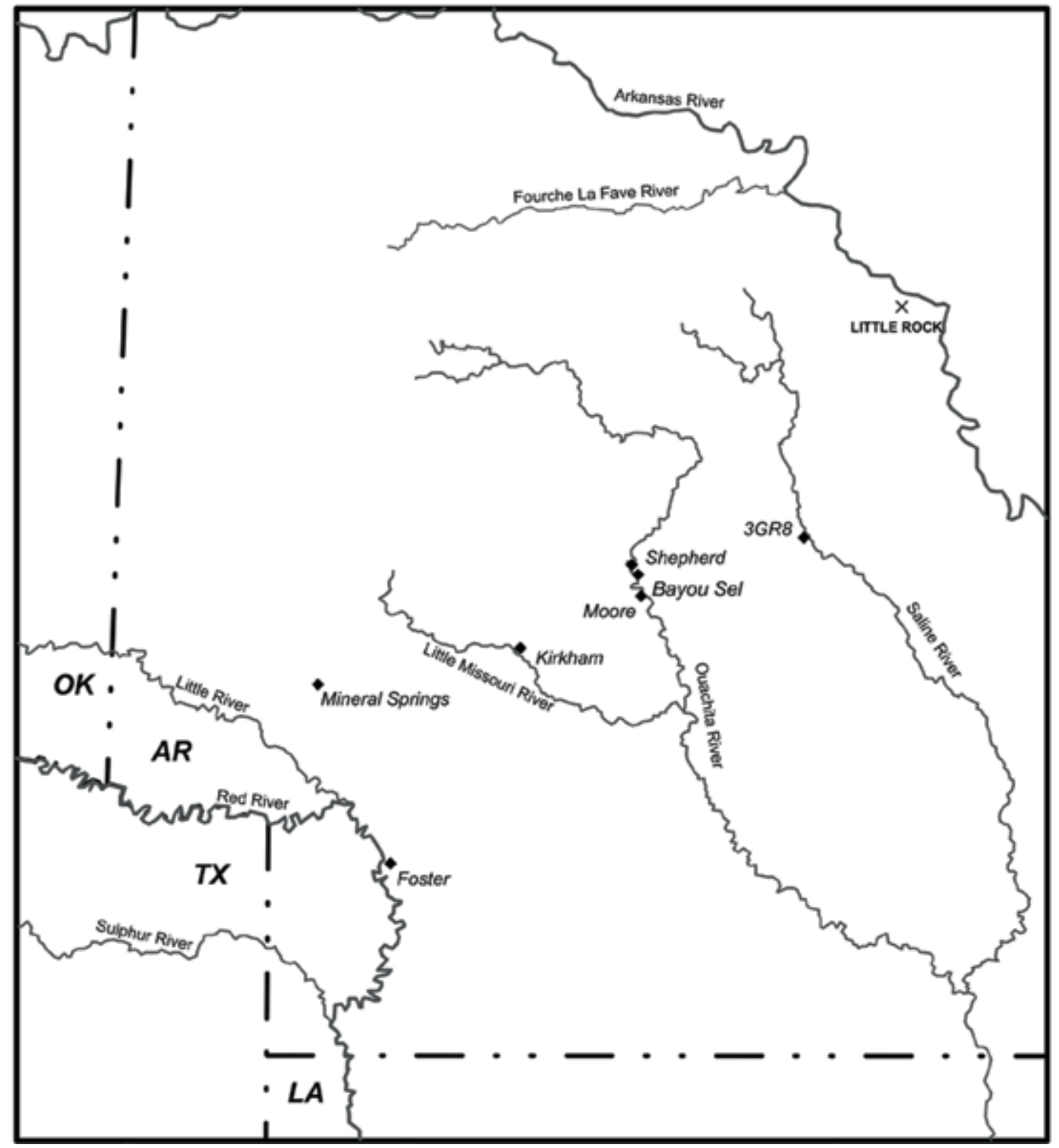

Figure 1. Sites in southwest Arkansas with marine shell gorgets.

The Bayou Sel gorget apparently came from a burial exposed by bulldozing and/or dug by local collectors in 1972 and was reported to have been associated with several vessels including Friendship Engraved and Military Road Incised types (typical of the Mid-Ouachita phase, A.D. 1400-1500). It was donated to the AAS/HSU station in Arkadelphia by Dale Patrick, and accessioned in 1974. The gorget is not engraved, but has smoothed edges and a pair of drilled suspension holes (Figure 2). One of the holes is broken open. The artifact measures $9.2 \times 8.3 \mathrm{~cm}$ and is oval in shape. The original shell surface has been worn away, presumably pre-deposition. It is made from marine Busycon or whelk shell. 

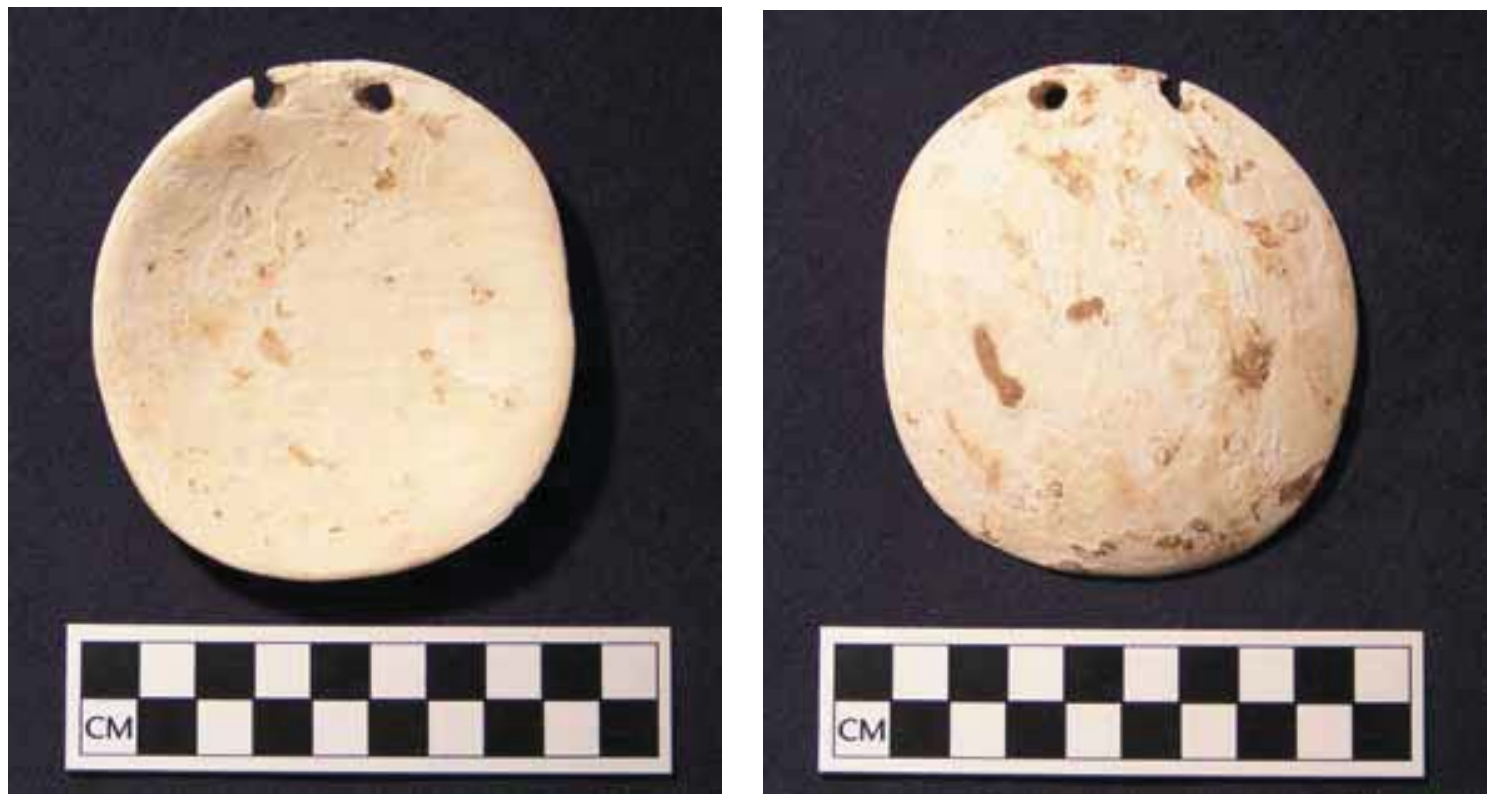

Figure 2. Plain shell gorget from Bayou Sel (AAS/HSU D_K1113 and 1116, 74-248, 3CL27).

The second piece is an engraved gorget from the Shepherd site (3CL39, AAS accession number 74-249) (Figure 3). Not much is known about the Shepherd or Evans Mound site, but it had several areas of artifact concentrations including one with Archaic period stone tools and another with ceramic sherds around a mound that was destroyed by 1967. The gorget was donated to the AAS/HSU station in Arkadelphia by Dale Patrick, who had acquired it following bulldozing operations at the site in the mid-1960s. Reportedly associated with the gorget were two seed jars and a Friendship Engraved bowl, suggesting a Mid-Ouachita phase context (A.D. 1400-1500).
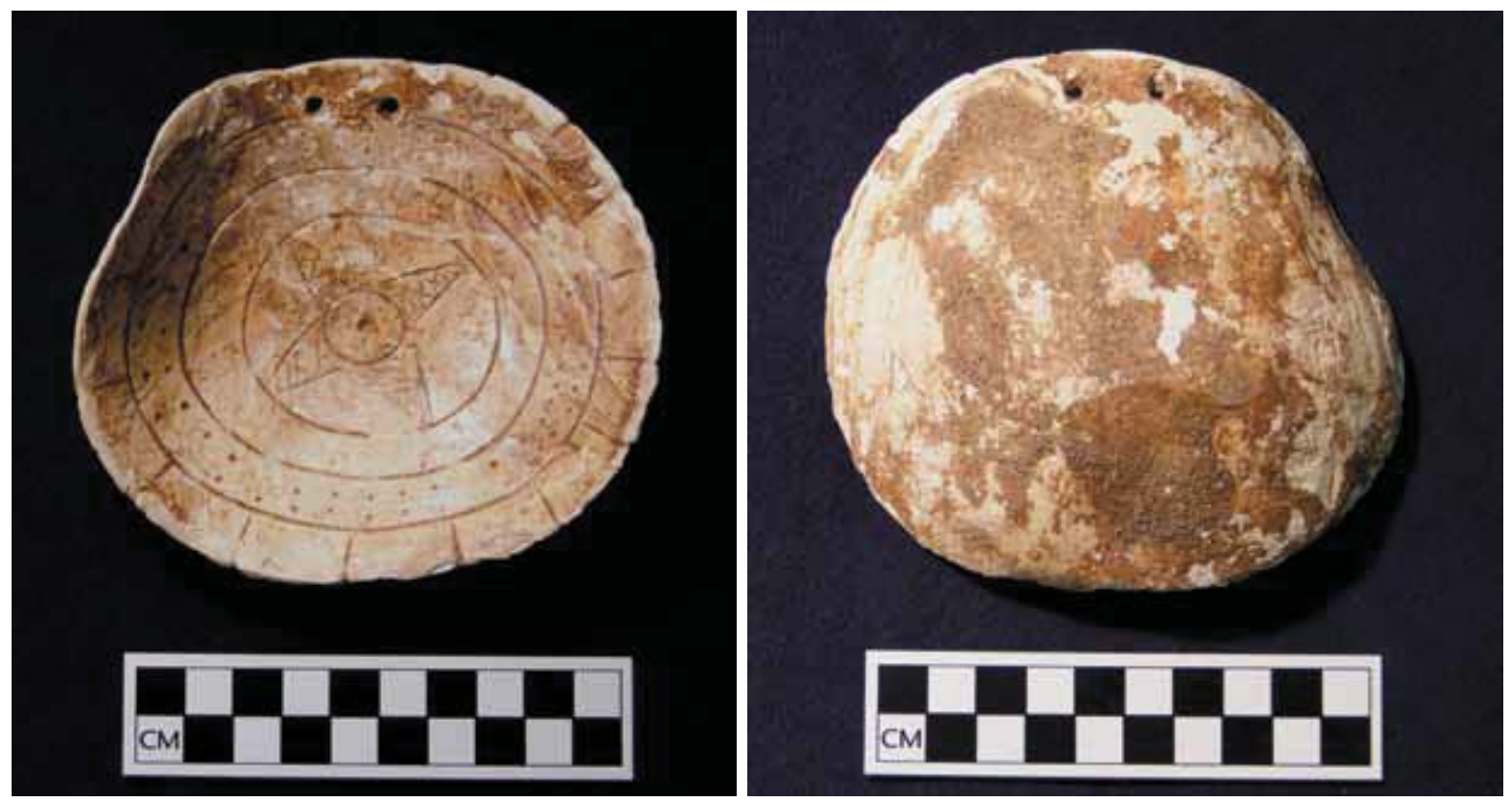

Figure 3. Engraved shell gorget from Shepherd (AAS/HSU D_K1119 and 1122, 74-249, 3CL39). 
The Shepherd gorget has an irregular circular shape, has two drilled suspension holes, and is engraved on the interior of the shell (Figure 3). It is made from marine shell, presumably Busycon or whelk shell, and measures $11.2 \times 11.7 \mathrm{~cm}$. The edges were cut and smoothed, and most of the outer shell surface is intact, but it looks like a coating was put on the artifact as a preservative following excavation. The engraved design is based on concentric circles with a four-pointed cross with circle and dot in the center. The outer edge has engraved lines to form a somewhat abstracted scalloped outer edge. The next band, formed by engraved concentric circular lines, is filled with engraved dots or punctations. The central element is a four-pointed cross-hatched cross with a circle and dot forming the center.

In addition to these two gorgets, there are two others that are known from AAS/HSU station photographic records but are not curated by the Survey. A plain shell gorget was photographed in 1974 by Ann Early during documentation of local amateur Hoy Furr's collection (Figure 4). This gorget reportedly came from a burial at the Moore Mound site (3CL56). Moore, like Bayou Sel, lies on the Ouachita River. Part of one mound remains today where there were once three mounds and associated cemetery and residential areas. While no professional archeological excavations have taken place, artifacts noted from the site indicate a Mid-Ouachita to Social Hill phase occupation (A.D. 1400-1650). The marine shell artifact illustrated has an irregular circular shape with some breakage around the edges, and has two drilled suspension holes. There is no visible engraving or decoration. According to notes provided by Furr, this gorget was found in a child's grave that had been dug by Furr and Gene Hudnall in "House site \#3" at Moore in 1974.

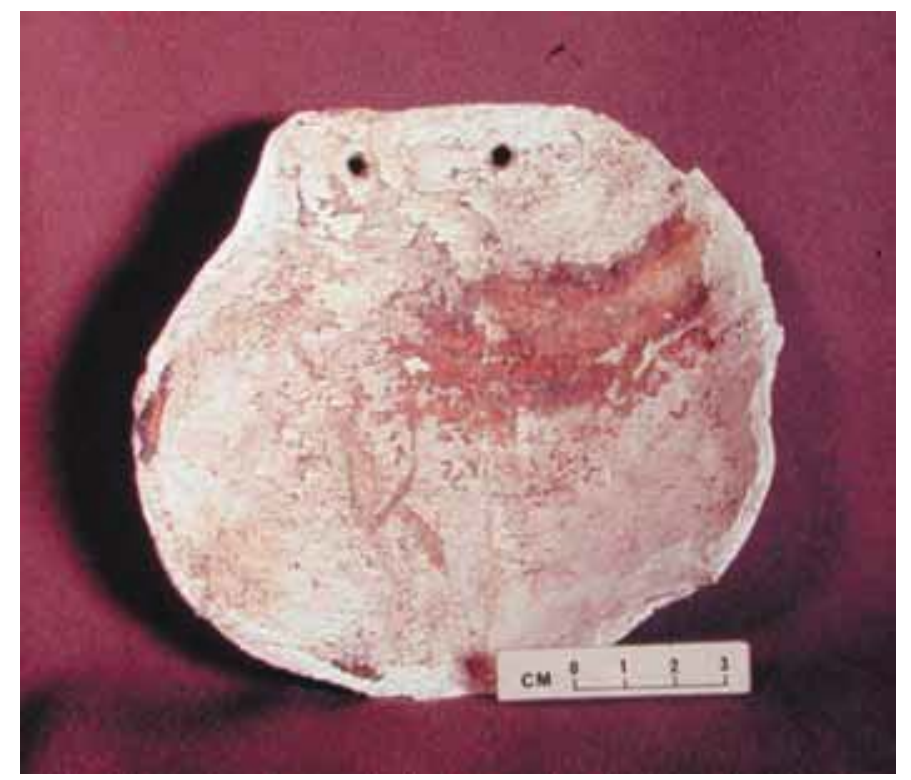

Figure 4. Plain shell gorget from Moore site, Furr Collection (AAS/HSU slide 1333).

In 1973, Ann Early photographed an engraved shell gorget in the Grant County Museum that was reportedly from site 3GR8 (Figure 5). This Grant County site near the Saline River was first recorded in 1961 as a mound and midden damaged by road construction and looting. In addition to the shell gorget, a Hempstead Engraved bowl also attributed to 3GR8 was photographed at the Grant County Museum, suggesting a Middle Caddo period (A.D. 1200-1400) date for the site. The small shell gorget or pendant has a notched or serrated edge and engraved double hand motif. Portions of the finger areas have broken away. Early described the gorget as having an eye-in-hand motif, although circles/crosses or other decoration on the palms of the hands cannot be seen in the photograph. Hand-shaped gorgets are unusual; Brain and Phillips $(1996: 446,490)$ illustrate one from Spiro (see also Brown 1996:595, Fig. 2-134c) and one from Castillian Springs in Tennessee. 


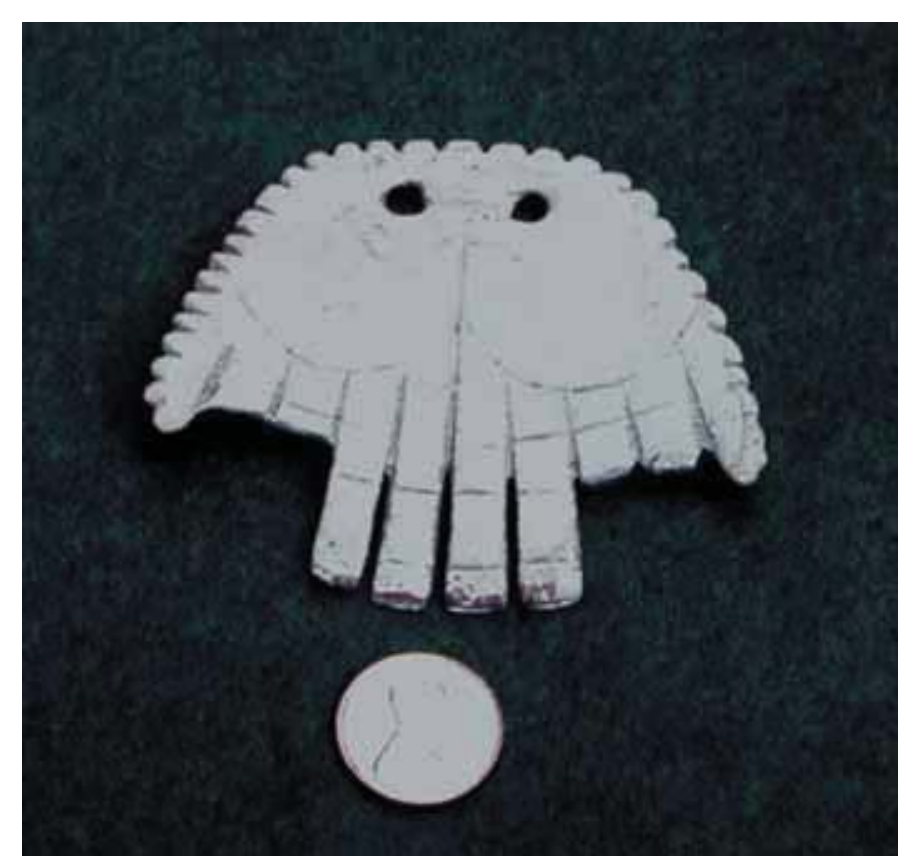

Figure 5. Engraved shell gorget or pendant from 3GR8, Grant County Museum Collection (AAS/HSU slide 1092).

The engraved design of the Shepherd gorget is similar to another example from Clark County from the Kirkham site (3CL29, Clark County) described in a short Arkansas Archeologist article by Meeks Etchieson (1981). Kirkham, in the Little Missouri River drainage, is a multicomponent site with Archaic, Woodland, and Mississippian (Caddo) period materials noted. A mound had been reported at the site but was leveled during the 1960s. The Kirkham gorget was a surface find but assumed to be associated with the Caddo occupation at the site. It measures $10.8 \times 10.5 \mathrm{~cm}$ and is irregularly circular in shape. As described and illustrated by Etchieson $(1981: 1,3)$, this shell gorget has scalloped edges and a series of engraved concentric circles or bands, two of which have dots or punctations. In the middle is a curved line "swastika" with a central cross in circle. The Kirkham gorget has also been illustrated by Brain and Phillips (1996:414), and described as a variant of the scalloped triskele or Nashville style. The differences seen by Brain and Phillips (1996:121) include the 4-armed motif ("tetraskelion") rather than the 3-armed triskele, the central cross-and-circle, and the two pitted or dotted bands separated by a plain band rather than an "ophidian" band made up of pitted circles arranged in a pitted background. The Kirkham gorget, with its scalloped edge, concentric bands with dots, and central curved-line element, is very similar to one from the Sam Kaufman site (Texas) that was found in a shaft grave dated to 1300-1500 A.D. (Skinner et al. 1969:98). It also resembles certain East Tennessee engraved gorgets. Sullivan (2007) places the Dallas site examples, including the 'scalloped triskele' or Nashville style gorgets, in the A.D. 1350-1450 time frame.

Two engraved shell gorgets were described and illustrated by C. B. Moore (1912:599-600) from Burial No. 10 at the Foster Place (3LA27, Lafayette County) on the Red River. Foster had two mounds, one of which had burials that were dug by Moore. Based on associated ceramics, Foster Place was included (with the last two occupations at Belcher Mound) in the Belcher Focus by Webb (1959, now termed Belcher phase, ca. A.D. 1500-1650). Other marine shell from Foster described by Moore included shell beads, disks, ear ornaments, and Busycon shell cups, one of which had an engraved decoration. Both of the Foster gorgets are circular in shape, engraved on the shell interior, have paired suspension holes, and have fenestration in addition to engraved decoration. One has been described by Brain and Phillips (1996:121) as a variant of the triskele category, but has spaced scallops around the outer edge, each with a circle and pit or dot, a band of 
engraved diamond shapes with pits in the "ophidian" band, and a fenestrated 4-armed "tetraskelion" with an engraved central circle and pit. The second Foster gorget is described by Brain and Phillips (1996:35) as a variant in the cruciform category. The central motif is a fenestrated cross with engraved lines and dots or pits with a central circle and pit. The cross is surrounded with engraved circles with pits. Towards the outer edge are a series of engraved or cut triangles with perforations in them. Webb (1959) highlighted engraved shell from both Foster and Belcher as examples of Southern Cult.

One marine shell gorget was excavated from the Mineral Springs site (3H01, Howard County). It is described by Bohannon (1973) as a conch shell gorget measuring $12.0 \times 10.9 \mathrm{~cm}$. "The surface was badly weathered but a simple design of closely set parallel lines traversing the specimen could still be discerned," (Bohannon 1973:59). The decoration is not clear on the illustrated artifact, but one perforation can be seen (Bohannon 1973:Fig. 17m). The gorget was excavated from Burial 12, Mound 6, by Clarence Webb in the 1950s. Burial 12 was a large pit with two skeletons and grave goods that indicate Mineral Springs/Haley phase deposition (ca. A.D. 1300-1400; Bohannon 1973; Hoffman 1983).

The marine shell gorgets from Caddo sites in southwest Arkansas are few in number, but point to some interesting issues in terms of the timing and routes of shell goods exchanged across the Southeast during the Mississippian period. The shell gorgets described here from sites in southwest Arkansas were excavated from burials, where context is known. The timing of deposition was during the Middle Caddo period (A.D. 12001400) for the Mineral Springs gorget and probably also for the Grant County Museum gorget, but during the Late Caddo period (A.D. 1400-1600) for the Bayou Sel, Moore Mound, Shepherd, and Foster Place gorgets.

In a discussion of marine shell beads found in Ozark bluff shelter excavations in northwest Arkansas, Hilliard and Harcourt (1997) conclude that those examples were deposited between A.D. 1000-1350 and evidence connections with the Spiro mound center to the west. Certainly large numbers of marine shell artifacts have been found at Spiro. But marine shell has been uncovered at other sites in the southern Caddo area, beyond Arkansas. Twenty-one marine shell gorgets were found at Sanders, a Middle Caddo period site near the Red River in east Texas (Jackson et al. 2000). Two engraved shell gorgets were found at Sam Kaufman, another Red River Valley site, probably dating to the Late Caddo period (Harris 1953; Skinner et al. 1969). And one engraved shell gorget was apparently found at the Historic Caddo period (A.D. 1680-1860) Clements site in northeast Texas (Perttula et al. 2005). One engraved/fenestrated marine shell gorget was excavated from the Late Caddo period Belcher site in the Red River drainage in northwest Louisiana (Webb 1959).

This short article is intended to publish descriptions and photographs of two marine shell gorgets from Caddo sites in Clark County, Arkansas, that are curated by the Arkansas Archeological Survey. In addition, photographs on file at the AAS/HSU station provide information about two gorgets from Clark and Grant counties that are in other collections. Summary descriptions of several previously published gorgets (from Kirkham, Foster, and Mineral Springs) are provided as well. Marine shell gorgets are relatively rare in southwest Arkansas. Busycon shell cups (most undecorated) seem to have been a more frequent form of marine shell in grave contexts in this region. And the small engraved zoomorphic pendants found at several Belcher phase sites seem to me to have been a local form of shell art. 


\section{References Cited}

Bohannon, Charles F.

1973 Excavations at the Mineral Springs Site. Research Series No. 5, Arkansas Archeological Survey, Fayetteville.

Brain, Jeffrey P. and Philip Phillips, with the assistance of Susan P. Sheldon

1996 Shell Gorgets: Styles of the Late Prehistoric and Protohistoric Southeast. Peabody Museum Press, Peabody Museum of Archaeology and Ethnology, Harvard University, Cambridge.

Brown, James

1996 The Spiro Ceremonial Center: The Archaeology of Arkansas Valley Caddoan Culture in Eastern Oklahoma. Memoir No. 29, Museum of Anthropology, University of Michigan, Ann Arbor.

2007 Sequencing the Braden Style within Mississippian Period Art and Iconography. In Ancient Objects and Sacred Realms: Interpretations of Mississippian Iconography, edited by F. Kent Reilly III and James F. Garber, pp. 213-245. University of Texas Press, Austin.

Early, Ann M.

2002a Arkansas Prehistory and History in Review: The East Phase. Field Notes (Newsletter of the Arkansas Archeological Society) 304:4-8.

2002b The Mid-Ouachita Phase. Field Notes (Newsletter of the Arkansas Archeological Society) 305:1013.

2002c Arkansas Prehistory and History in Review: The Social Hill Phase. Field Notes (Newsletter of the Arkansas Archeological Society) 306:10-13.

Early, Ann M., editor.

1993 Caddoan Saltmakers in the Ouachita Valley: The Hardman Site. Research Series No. 43. Arkansas Archeological Survey, Fayetteville.

Early, Ann M., with Barbara A. Burnett and Daniel Wolfman

1988 Standridge: Caddoan Settlement in a Mountain Environment. Research Series No. 29. Arkansas Archeological Survey, Fayetteville.

Etchieson, G. Meeks

1981 A Shell Gorget from the Kirkham Site. The Arkansas Archeologist (Bulletin of the Arkansas Archeological Society) 22:1-3.

Hally, David J.

2007 Mississippian Shell Gorgets in Regional Perspective. In Southeastern Ceremonial Complex: Chronology, Content, Context, edited by Adam King, pp. 185-231. University of Alabama Press, Tuscaloosa.

Harrington, Mark R.

1920 Certain Caddo Sites in Arkansas. Indian Notes and Monographs, Museum of the American Indian, Heye Foundation, New York.

Harris, R. K.

1953 The Sam Kaufman Site, Red River County, Texas. Bulletin of the Texas Archeological and Paleontological Society 24:43-68. (Reprinted in Classics in Texas Archeology: Selected Articles from the Early Years of the Bulletin of the Texas Archeological Society. Volume 1, Caddo Archeology, edited by Timothy K. Perttula, pp. 245-272. Gustavs Library, 2009.) 
Hilliard, Jerry and James Harcourt

\section{References Cited (Cont.)}

1997 Marine Shell Beads from the University of Arkansas Museum Bluff Shelter Excavations. The Arkansas Archeologist (Bulletin of the Arkansas Archeological Society) 36 (for 1995):35-45

Hoffman, Michael P.

1970 Archaeological and Historical Assessment of the Red River Basin in Arkansas. In Archeological and Historical Resources of the Red River Basin, edited by Hester A. Davis, pp. 135-194. Publications on Archeology, Research Series No. 1, Arkansas Archeological Survey, Fayetteville.

1983 Changing Mortuary Patterns in the Little River Region, Arkansas. In Southeastern Natives and Their Pasts: A Collection of Papers Honoring Dr. Robert E. Bell, edited by Don G. Wyckoff and Jack L. Hofman, pp. 163-182. Studies in Oklahoma's Past No. 11, Oklahoma Archeological Survey, and Contribution No. 2, Cross Timbers Heritage Association, Norman.

Jackson, A. T., Marcus S. Goldstein, and Alex D. Krieger

2000 The 1931 Excavations at the Sanders Site, Lamar County, Texas: Notes on the Fieldwork, Human Osteology, and Ceramics. Archival Series 2, Texas Archaeological Research Laboratory, University of Texas, Austin.

Lankford, George E.

2007 Some Cosmological Motifs in the Southeastern Ceremonial Complex. In Ancient Objects and Sacred Realms: Interpretations of Mississippian Iconography, edited by F. Kent Reilly III and James F. Garber, pp. 8-38. University of Texas Press, Austin.

Moore, Clarence B.

1912 Some Aboriginal Sites on Red River. Journal of the Academy of Natural Sciences of Philadelphia, Second Series, Vol. XIV, pp. 483-638. Philadelphia.

Muller, Jon

1997 Mississippian Political Economy. Plenum Press, New York.

Perttula, Timothy K., Bo Nelson, Robert L. Cast, and Bobby Gonzalez

2005 The W. T. Scott Collection at the American Museum of Natural History. In A Rediscovering of Caddo Heritage: The W. T. Scott collection at the American Museum of Natural History and Other Caddo Collections from Arkansas and Louisiana, by Bobby Gonzalez, Robert Cast, Timothy K. Perttula, and Bo Nelson, pp. 25-53. Historic Preservation Program, Caddo Nation of Oklahoma, Binger.

Phillips, Philip and James A. Brown

1978 Pre-Columbian Shell Engravings from the Craig Mound at Spiro, Oklahoma. Paperback ed., Part 1. Peabody Museum of Archaeology and Ethnology, Harvard University. Cambridge: Peabody Museum Press.

Reilly, F. Kent

2007 The Petaloid Motif: A Celestial Symbolic Locative in the Shell Art of Spiro. In Ancient Objects and Sacred Realms: Interpretations of Mississippian Iconography, edited by F. Kent Reilly III and James F. Garber, pp. 39-55. University of Texas Press, Austin.

Skinner, S. Alan, R. King Harris, and Keith M. Anderson, editors.

1969 Archaeological Investigations at the Sam Kaufman Site, Red River County, Texas. Contributions in Anthropology No. 5, Department of Anthropology, Southern Methodist University, Dallas. 


\section{References Cited (Cont.)}

Smith, Kevin E. and Emily L. Beahm

2009 Corrected Provenance for the Long-Nosed God Mask from "A Cave near Rogana, Tennessee." Southeastern Archaeology 28(1):117-121.

Sullivan, Lynne P.

2007 Shell Gorgets, Time, and the Southeastern Ceremonial Complex in Southeastern Tennessee. In Southeastern Ceremonial Complex: Chronology, Content, Context, edited by Adam King, pp. 88106. University of Alabama Press, Tuscaloosa.

Trubowitz, Neal L., editor.

1984 Cedar Grove: An Interdisciplinary Investigation of a Late Caddo Farmstead in the Red River Valley. Research Series No. 23. Arkansas Archaeological Survey, Fayetteville.

Webb, Clarence $\mathrm{H}$.

1959 The Belcher Mound; A Stratified Caddoan Site in Caddo Parish, Louisiana. Memoirs No. 16, Society for American Archaeology, Salt Lake City. 